\title{
Ultrafiltration of skimmed goat milk increases its nutritional value by concentrating nonfat solids such as proteins, $\mathrm{Ca}, \mathrm{P}, \mathrm{Mg}$, and $\mathrm{Zn}$
}

\author{
Miriam Moreno-Montoro, ${ }^{* 1}$ Manuel Olalla, ${ }^{*}$ Rafael Giménez-Martínez, ${ }^{*}$ Triana Bergillos-Meca, ${ }^{*} \dagger$ \\ María Dolores Ruiz-López, ${ }^{*}$ Carmen Cabrera-Vique, ${ }^{*}$ Reyes Artacho, ${ }^{*}$ and Miguel Navarro-Alarcón* \\ *Departmento de Nutrición y Bromatología, Facultad de Farmacia, University of Granada, Campus de Cartuja s/n, 18071, Granada, Spain \\ †Department of Food and Nutritional Sciences, PO Box 226 Whiteknights, Reading, RG6 6AP, United Kingdom
}

\begin{abstract}
Goat milk has been reported to possess good nutritional and health-promoting properties. Usually, it must be concentrated before fermented products can be obtained. The aim of this study was to compare physicochemical and nutritional variables among raw $(\mathrm{RM})$, skimmed (SM), and ultrafiltration-concentrated skimmed (UFM) goat milk. The density, acidity, ash, protein, casein, whey protein, $\mathrm{Ca}, \mathrm{P}, \mathrm{Mg}$, and $\mathrm{Zn}$ values were significantly higher in UFM than in RM or SM. Dry extract and fat levels were significantly higher in UFM than in SM, and Mg content was significantly higher in UFM than in RM. Ultrafiltration also increased the solubility of $\mathrm{Ca}$ and $\mathrm{Mg}$, changing their distribution in the milk. The higher concentrations of minerals and proteins, especially caseins, increase the nutritional value of UFM, which may therefore be more appropriate for goat milk yogurt manufacturing in comparison to RM or SM.
\end{abstract}

Key words: goat milk, ultrafiltration, protein, minerals

\section{INTRODUCTION}

Goat milk is known to have a superior mineral composition and bioavailability in comparison to cow milk (Raynal-Ljutovac et al., 2008). The concentration of proteins is lower in goat than in cow milk, but their digestibility and biological values are higher (RamosMorales et al., 2005); likewise, goat milk has been recommended as an alternative to cow milk in patients with malabsorption syndrome (Lara-Villoslada et al., 2004). However, little research has been published on the distribution of minerals among the different protein fractions, which has a major influence on their bioavailability (de la Fuente et al., 1999).

Received June 10, 2015.

Accepted July 19, 2015.

${ }^{1}$ Corresponding author: mmorenom@ugr.es
The consistency of goat yogurt is a key parameter in its manufacture, and improvement of its texture and rheological properties requires modification of the native compositions of the milk used (Domagała, 2009). Methods applied to enhance the sensory quality of fermented goat milk products usually involve an increase in their SNF or protein content. Because heating-based methods are known to diminish the nutritional value of the added milk or proteins, alternative techniques have been used, including the concentration of the milk with membranes, the addition of pectin and inulin, or even the addition of lactic acid bacteria as exopolysaccharide producers (Martin-Diana et al., 2003; Karam et al., 2013). Milk UF has been reported as a good concentration approach that does not impair the nutritional value of the milk, and the resulting fermented milks were reported to have better textural and sensorial characteristics and improved nutritional values (e.g., proteins, Ca, and Fe; Rinaldoni et al., 2009; Domagała, 2012).

With this background, the main objective of the present study was to measure and compare the levels of physicochemical and nutritional parameters during the different steps of milk concentration by UF. A secondary objective was to investigate the influence of the UF process on the different protein fractions of the milk and on the distribution of $\mathrm{Ca}, \mathrm{P}, \mathrm{Mg}$, and $\mathrm{Zn}$ among these fractions, which may affect the bioaccessibility and bioavailability of these minerals. These data are relevant to the utilization of ultrafiltration in goat yogurt production.

\section{MATERIALS AND METHODS}

\section{Samples}

Raw goat milk produced by goats of the MurcianoGranadina breed was collected monthly from a farm in Granada province (southern Spain) over a period of $1 \mathrm{yr}$ to avoid seasonal variations. After heating at 30 to $35^{\circ} \mathrm{C}$, the raw goat milk (RM) was skimmed using a centrifuge with stainless steel plates (S.Q. Ar- 
royo, Santander, Spain). The raw skimmed goat milk (SM) was then concentrated by UF through a $50-\mathrm{kDa}$ membrane (Vivaflow 2000, Sartorius Stedim Biotech, Madrid, Spain) using a peristaltic pump (Masterflex L/S, Economy Drive, Cole Parmer, Vernon Hills, IL) at $150 \mathrm{kPa}$ pressure to a volume concentration ratio of 1.7, as described by Bergillos-Meca et al. (2015). This milk was then subjected to heat treatment at $82 \pm 1^{\circ} \mathrm{C}$ for $30 \mathrm{~min}$, obtaining the final ultrafiltration-skimmed goat milk (UFM). A total of 36 samples were studied, 12 of each type (RM, SM, and UFM).

\section{Physicochemical Parameters in Goat Milks}

The official methods proposed by AOAC International (2012) were followed to establish the milk density, $\mathrm{pH}$, total acidity, dry extract (TS), and ash. A Crison Basic $20+$ pH-Meter (Barcelona, Spain) coupled to a Hamilton Polilyte Lab electrode (Bonaduz, Switzerland) was used to measure the $\mathrm{pH}$ and acidity. The acidity was measured by potentiometric titration with $\mathrm{NaOH}$ up to $\mathrm{pH}$ 8.4. To obtain ash, the milk was incinerated at $550 \pm 5^{\circ} \mathrm{C}$ in a muffle furnace (Nabertherm, LE 2/11/ R6, Bremen, Germany). All analyses were carried out in triplicate. Blanks were prepared with bidistilled deionized water, obtained by filtration through a Milli-Q purifier (Millipore, Waters, Milford, MA), instead of the sample.

\section{Nutritional Parameters in Goat Milks}

Lactose levels were analyzed by using the standardized method for milk (Casado Cimiano, 1991). Fat concentrations were measured in accordance with ISO (2008). Noncasein nitrogen (NCN) and NPN were separated, as described elsewhere, to determine the nitrogen in these fractions and total nitrogen in goat milks by means of the Kjeldahl method (Olalla et al., 2009). A recovery rate of $98 \%$ was obtained using BSA (Sigma-Aldrich, Steinheim, Germany). Levels of total proteins, caseins, and whey proteins were calculated according to Olalla et al. (2009). The reagents used for separation of milk fractions were the glacial acetic acid (99\%), TCA (99.0-100.5\%), and sodium acetate trihydrate (99.0-100.1\%; Panreac, Castellar del Vallès, Spain). The reagents used for the Kjeldahl method were sulfuric acid (95-97\%; Merck, Darmstadt, Germany), copper (II) sulfate 5-hydrate (99.0-100.5\%; Panreac), potassium sulfate (99\%), sodium hydroxide (98.0-100.5\%), and Tashiro's indicator solution in methanol (Sigma-Aldrich).

Mineral (Ca, P, Mg, and $\mathrm{Zn}$ ) levels in milk samples and nitrogen fractions were measured using previously optimized procedures (Bergillos-Meca et al., 2013). Standard solutions of Ca, P, Mg, and Zn [1.000 \pm 0.002 $\mathrm{mg} / \mathrm{L}(\mathrm{SD})]$ were purchased from Tritisol (Merck), and ammonium molybdate (99.3-101.8\%), 2,4-diaminophenol-digydrochlorid ( $>97 \%)$, and sodium disulfite (97\%) from Panreac were used for the mineral determinations.

Dry mineralization was measured from the ash of the goat milk samples, which were first weighed and then diluted with $3 \mathrm{~mL}$ of $0.1 \mathrm{~N}$ chloridric acid (from chloridric acid $37 \%$, Suprapur, Merck) and brought to a volume of $25 \mathrm{~mL}$ with bidistilled water (Navarro-Alarcón et al., 2011). Minerals in nitrogen fractions were directly measured. The formula used for proteins (see above) was applied to calculate the amount of minerals bound to the different proteins, based on the data obtained on the minerals in each fraction and the total minerals in the milk sample.

The risk of contamination was reduced by using polypropylene vessels and pipette tips and only a minimum amount of glassware. In addition, all material was nitric acid (30\% vol/vol; Panreac,), washed and rinsed several times with bidistilled deionized water.

The analytical procedures used to measure $\mathrm{Ca}, \mathrm{Mg}$, and $\mathrm{Zn}$ levels by flame atomic absorption spectrometry were previously optimized and reported (MorenoTorres et al., 2000; Navarro-Alarcón et al., 2011). Calcium, $\mathrm{Mg}$, and $\mathrm{Zn}$ were determined by direct aspiration into the flame of the atomic absorption spectrometer (Perkin-Elmer 1100B double beam; Perkin-Elmer, Norwalk, CT) at wavelengths of $422.7 \mathrm{~nm}$ for $\mathrm{Ca}, 285.2$ $\mathrm{nm}$ for $\mathrm{Mg}$, and $213.9 \mathrm{~nm}$ for $\mathrm{Zn}$, using hollow cathode lamps (Perkin-Elmer). Calcium levels were measured by the standard addition method with lanthanum (III) chloride ( $>98 \%$ from Suprapur, Merck) as a matrix modifier to avoid matrix interferences, whereas $\mathrm{Mg}$ and Zn were determined by the linear calibration method. Phosphorus levels were measured with a spectrophotometer (Perkin-Elmer Lambda 25 UV-VIS; PerkinElmer) set at $750 \mathrm{~nm}$ with a band-pass setting of $1 \mathrm{~nm}$, as previously reported (Bergillos-Meca et al., 2013).

The analytical characteristics of the methods used for the $\mathrm{Ca}, \mathrm{P}, \mathrm{Mg}$, and $\mathrm{Zn}$ measurements were evaluated, establishing the detection limit and sensitivity for each (Table 1). The interday repeatability and percentage recovery of added $\mathrm{Ca}, \mathrm{P}, \mathrm{Mg}$, and $\mathrm{Zn}$ were adequate for the measurement of these elements in goat milks (Table 1). The accuracy and precision of the $\mathrm{Ca}, \mathrm{P}, \mathrm{Mg}$, and $\mathrm{Zn}$ measurement techniques were also verified by testing 2 certified reference standards: CRM 063 skim milk powder (Community Bureau of Reference, Commission of European Communities) and SRM standard reference material (SRM NIST 1572 citrus leaves; National 
Table 1. Analytical parameters of methods used to determine $\mathrm{Ca}, \mathrm{P}, \mathrm{Mg}$, and $\mathrm{Zn}$ in goat milks

\begin{tabular}{lcccc}
\hline Element & $\begin{array}{c}\text { Detection } \\
\text { limit }^{1}\end{array}$ & $\begin{array}{c}\text { Characteristic }_{\text {mass }^{2}(\mathrm{ng})} \\
(\%, \text { mean } \pm \mathrm{SD})\end{array}$ & $\begin{array}{c}\text { Precision, }_{\text {RSD }^{4}(\%)} \\
\mathrm{Ca}\end{array} \mathrm{Recovy}^{3}$ \\
$\mathrm{P}$ & 110.0 & 46.0 & $100.49 \pm 1.06$ & 1.72 \\
$\mathrm{Mg}$ & 5.0 & 172 & $100.67 \pm 2.09$ & 4.03 \\
$\mathrm{Zn}$ & 11.6 & 58.0 & $100.09 \pm 0.87$ & 3.16 \\
\hline
\end{tabular}

${ }^{1}$ Detection limit units are expressed as $\mathrm{ng} / \mathrm{mL}$ for $\mathrm{Zn}, \mathrm{Ca}, \mathrm{Mg}$, and $\mathrm{P}$.

${ }^{2}$ Characteristic mass corresponding to 0.0044 milli-absorbance units.

${ }^{3}$ Mean recovery obtained by analyte recovery assays in 4 fractions of the analyte in the same sample.

${ }^{4}$ Mean relative standard deviation (RSD) obtained by repeated measurements $(n=7)$ in 4 fermented goat milks (interday variability).

Institute of Standards and Technology). No significant differences were found between the mean $\mathrm{Ca}, \mathrm{P}, \mathrm{Mg}$, and $\mathrm{Zn}$ concentrations determined in these materials and the certified concentrations (Table 2). All analyses were carried out in triplicate. Blanks were prepared with bidistilled deionized water instead of the sample.

\section{Statistical Analysis}

The homogeneity of variances was first assessed with the Levene test at a significance level of $P<0.05$. The normal distribution of data was assayed with the Shapiro-Wilk test at a significance level of $P<0.05$. The ANOVA was performed using the Student's $t$-test when parametric conditions were met and the Kruskall-Wallis test when they were not. Pearson linear correlation was performed for the regression analysis between study variables when the data were normally distributed and the Spearman linear correlation when they were not. SPSS 17.0 (Windows version; SPSS Inc., Chicago, IL) was used for the statistical analyses; significance levels were set at $P<0.05$.

\section{RESULTS AND DISCUSSION}

Results of the physicochemical and nutritional analyses of the samples are displayed in Table 3.

\section{Physicochemical Parameters}

The dry extract, which largely depends on the milk fat content, was significantly higher in RM than in SM and UFM, but within the range reported by other researchers (12.3-15.9\%; Quiles Sotillo and Hevia Méndez, 1994; Güler-Akın and Akın, 2007). The TS content of UFM, which was significantly higher than that of SM, was within the range considered optimal for milk to achieve the ideal yogurt consistency (12-14\%; Tamime and Robinson, 2007). When the dry extract values were obtained by adding whey protein concentrate, sodium caseinate, or skim milk powder (13.57, 12.14 , and $13.89 \%$ of dry extract, respectively), protein concentrations were lower $(4.90,4.93$, and $4.92 \mathrm{~g} / 100 \mathrm{~g}$, respectively; Marafon et al., 2011) than those obtained in UFM (6.07 g/100 g; Table 3). Ash levels were significantly higher for UFM than for RM and SM, which both had ash levels within the range of previous reports (from 0.75 to 0.82; Stelios and Emmanuel, 2004; GülerAkin et al., 2009; Sanz Ceballos et al., 2009).

Milk density is not a constant physicochemical parameter because it depends on milk SNF as well as on fat levels. The density of all samples was within the range reported for bovine milk (1.026-1.042 g/ mL; Quiles Sotillo and Hevia Méndez, 1994), although slightly higher values have previously been observed in

Table 2. Determination of $\mathrm{Ca}, \mathrm{Mg}$, and $\mathrm{Zn}$ by FAAS ${ }^{1}$ and of $\mathrm{P}$ by $\mathrm{UV}$-visible spectrophotometry in 2 certified reference materials (data refer to dry weight; mean $\pm \mathrm{SD}$ )

\begin{tabular}{|c|c|c|c|c|c|}
\hline \multirow[b]{2}{*}{ Element } & \multirow[b]{2}{*}{$\mathrm{n}$} & \multicolumn{2}{|c|}{ BCR-CRM 063R ${ }^{2}$} & \multicolumn{2}{|c|}{ NIST $1572^{2}$} \\
\hline & & Certified & Measured & Certified & Measured \\
\hline $\mathrm{Ca}(\mathrm{mg} / \mathrm{g})$ & 10 & $13.49 \pm 0.100$ & $13.21 \pm 0.150$ & - & - \\
\hline $\mathrm{P}(\mathrm{mg} / \mathrm{g})$ & 10 & $11.10 \pm 0.130$ & $11.01 \pm 0.210$ & - & - \\
\hline $\mathrm{Zn}(\mu \mathrm{g} / \mathrm{g})$ & 10 & $49.0 \pm 0.600$ & $48.50 \pm 2.32$ & $138.6 \pm 2.10$ & $136.6 \pm 2.90$ \\
\hline $\mathrm{Mg}(\mathrm{mg} / \mathrm{g})$ & 10 & $1.262 \pm 0.024$ & $1.258 \pm 0.042$ & $5.80 \pm 0.300$ & $5.34 \pm 0.250$ \\
\hline
\end{tabular}

${ }^{1}$ FAAS $=$ flame atomic absorption spectrometry.

${ }^{2}$ Reference value of the certified reference materials; CRM 063 skim milk powder (Community Bureau of Reference, Commission of European Communities) and SRM standard reference material (SRM NIST 1572 citrus leaves; National Institute of Standards and Technology). 
Table 3. Values of physicochemical and nutritional parameters in the 3 types of goat milk $^{1}$ analyzed (mean \pm SD)

\begin{tabular}{|c|c|c|c|c|}
\hline Parameter & $\mathrm{n}$ & $\mathrm{RM}$ & $\mathrm{SM}$ & UFM \\
\hline Ash $(\mathrm{g} / 100 \mathrm{~g})$ & 12 & $0.769 \pm 0.022^{\mathrm{a} * * *}$ & $0.800 \pm 0.076^{\mathrm{a} * * *}$ & $0.961 \pm 0.093^{\mathrm{b} * * *}$ \\
\hline Density $(\mathrm{g} / \mathrm{mL})$ & 12 & $1.030 \pm 0.002^{\mathrm{a} * * *}$ & $1.035 \pm 0.002^{\mathrm{b} * * *}$ & $1.043 \pm 0.002^{\mathrm{c} * * *}$ \\
\hline Acidity (g of lactic acid/100 g) & 12 & $0.130 \pm 0.016^{\mathrm{a} *}$ & $0.125 \pm 0.016^{\mathrm{a} *}$ & $0.143 \pm 0.016^{\mathrm{b} *}$ \\
\hline Lactose $(\mathrm{g} / 100 \mathrm{~g})$ & 12 & $4.71 \pm 0.18$ & $4.96 \pm 0.21$ & $4.92 \pm 0.22$ \\
\hline Fat $(\mathrm{g} / 100 \mathrm{~g})$ & 12 & $5.31 \pm 1.06^{\mathrm{a} * * *}$ & $0.05 \pm 0.04^{\mathrm{b} * * *}$ & $0.10 \pm 0.03^{\mathrm{c} * * *}$ \\
\hline Whey proteins ( $\mathrm{g} / 100 \mathrm{~g} ; \%$ proteins in parentheses) & 12 & $\begin{array}{l}0.73 \pm 0.08^{\mathrm{a} *} \\
\quad(20)\end{array}$ & $\begin{array}{l}0.73 \pm 0.04^{a *} \\
\quad(18)\end{array}$ & $\begin{array}{l}1.02 \pm 0.25^{\mathrm{b} *} \\
(18)\end{array}$ \\
\hline
\end{tabular}

${ }^{a-c}$ Different superscript letters indicate statistically significant differences for the same parameter within the same row.

${ }^{1} \mathrm{RM}=$ raw goat milk; $\mathrm{SM}=$ skimmed goat milk; UFM = skimmed goat milk concentrated by UF.

$* P<0.05 ; * * * P<0.001$.

most studies of goat milk (Park et al., 2007). The density values significantly differed among RM, SM, and UFM samples (Table 3), being lowest for RM (highest fat content) and highest for UFM (due to concentration into SNF).

The mean $\mathrm{pH}$ values of all milk samples were above the upper limit of the range reported for goat milk (6.3-6.8; Quiles Sotillo and Hevia Méndez, 1994; Güler, 2007; Table 3). The acidity was significantly higher in UFM than in RM or SM (Table 3), being within the range reported for raw goat milk by Park et al. (2007), but above that observed for raw cow milk by GülerAkin et al. (2009).

\section{Nutritional Parameters}

Fat content is the most quantitatively and qualitatively variable component of goat milk and depends on the lactation stage, season, breed, genotype, and feeding (Raynal-Ljutovac et al., 2008). The fat concentration of RM (Table 3) was within the range reported by other authors (3.1-5.3\%; Güler-Akin et al., 2009; Sanz Ceballos et al., 2009). The concentration was significantly higher in UFM than in SM, but both can be considered skim milks (Baró Rodríguez et al., 2010).

Goat milk was reported to cause less digestion difficulties in humans compared to cow milk due to its lower lactose content (Park et al., 2007). No significant differences among the present milk samples were observed in lactose concentrations (Table 3), which were above the previously reported range (4.11-4.86 g/100 g; Domagala and Kupiec, 2003; Sanz Ceballos et al., 2009; Slačanac et al., 2010). Hence, lactose concentrations were not affected by the UF process, contrasting with the report by Domagala and Kupiec (2003), who observed a significant reduction that was greater with larger pore size. This discrepancy may be explained by the differences in UF membranes and methods. The present milk types differed in protein concentration, which was significantly higher in UFM than in SM or RM (Table 3). The protein content of RM samples was within the range $(3.49-3.73 \mathrm{~g} / 100 \mathrm{~g})$ previously reported for milk from the Murciano-Granadina breed (Gonzalez-Crespo et al., 1995). Reported protein concentrations in milk from other breeds have ranged from 3.1 to $4.15 \mathrm{~g} / 100 \mathrm{~g}$ (Güler, 2007; Park et al., 2007; Tamime et al., 2011). The protein content of UFM was higher than the range $(5.22-5.49 \mathrm{~g} / 100 \mathrm{~g})$ previously reported in UF milks, indicating that a greater concentration was obtained with our process (Domagala and Kupiec, 2003).

The percentage casein values of RM and SM samples were within the previously reported range (79-83\% of proteins; Sanz Ceballos et al., 2009; Baró Rodríguez et al., 2010). They were significantly higher in UFM (85\%), probably because UF predominantly retains caseins, which is advantageous for yogurt production given that they are the most important proteins for curd formation in the fermentation process (Baró Rodríguez et al., 2010; Domagała, 2012). The mean concentration of whey proteins in RM was slightly higher than the previously reported range $(0.52-0.62 \mathrm{~g} / 100 \mathrm{~g}$; Olalla et al., 2009; Sanz Ceballos et al., 2009). A similar percentage of whey proteins was observed in all 3 milk types but their concentration was significantly higher in UFM (Table 3). Although the molecular weight of the major whey proteins ( $\beta$-LG and $\alpha-\mathrm{LA})$ is lower than the membrane cut-off value after heating, $\beta$-LG may in part bind (by hydrophobic or disulfide interactions) with $\alpha$-LA, $\kappa-\mathrm{CN}$, or BSA, forming complexes with a molecular weight above this cut-off value (Karam et al., 2013). Other whey proteins of higher molecular weight would also be retained, including immunoglobulins 
(around $15 \%$ of whey proteins), serum albumin, and lactoferrin (Baró Rodríguez et al., 2010).

Table 4 exhibits the total concentrations of $\mathrm{Ca}, \mathrm{P}$, $\mathrm{Mg}$, and $\mathrm{Zn}$ in the milk samples and the concentrations in NCN and NPN fractions. The highest concentrations of these minerals were found in the UFM samples, consistent with the finding that these samples had a significantly higher percentage of ash. Mean Ca, P, and Zn concentrations were significantly higher in UFM than in $\mathrm{RM}$ or $\mathrm{SM}$ samples, and mean $\mathrm{Mg}$ concentrations were significantly higher in UFM than in RM samples. The mean mineral concentrations in RM and SM were within previously reported ranges; concentrations were higher in UFM than previously reported in raw milk (Sanz Ceballos et al., 2009; Slačanac et al., 2010). The higher $\mathrm{Ca}, \mathrm{P}, \mathrm{Mg}$, and $\mathrm{Zn}$ levels in UFM may be attributable to their partial binding to caseins, resulting in their increase when caseins are concentrated by UF (de la Fuente et al., 1997).

Table 4 exhibits the mineral levels in NCN and NPN fractions obtained by the acidification method described above. Table 5 reports the percentages of minerals $(\mathrm{Ca}, \mathrm{P}, \mathrm{Mg}$, and $\mathrm{Zn}$ ) from the total soluble whey content or associated with proteins (caseins and whey proteins) in RM, SM, and UFM. Mean Ca, P, $\mathrm{Mg}$, and Zn levels in the NCN and NPN fractions were significantly higher in UFM than in RM or SM (Table 4). As shown in Table 5, the percentages of $\mathrm{Ca}$ and $\mathrm{Mg}$ bound to proteins were lower in UFM than in RM and $\mathrm{SM}$, indicating that the distribution of these minerals was modified by the UF process. It should be noted that all elements need to be in soluble form or bound to compounds forming soluble complexes to be absorbed in the intestinal tract (Roig et al., 1999).
The percentages of minerals bound to proteins after filtration or coagulation were reported to be $88 \%$ for Ca, $61 \%$ for P, 34\% for Mg, and $87 \%$ for Zn (Fransson and Lönnerdal, 1983; de la Fuente et al., 1996, 1997), very different from the present results, especially for Ca (only 16\%). It was previously reported that acid treatment modifies the distribution of minerals in milk (Fransson and Lönnerdal, 1983), which may increase $\mathrm{Ca}$ and $\mathrm{Mg}$ levels in the soluble fraction, as in the present observations. The increases in total $\mathrm{Ca}$ and $\mathrm{P}$ concentrations in UFM were not proportional, and the Ca-to-P ratio decreased from 1.36 and 1.39 in RM and SM, respectively, to 1.20 in UFM, which remains within the recommended range for good $\mathrm{Ca}$ absorption and bioavailability (Baró Rodríguez et al., 2010).

Pasteurization has been reported to reduce the soluble mineral fraction (de la Fuente et al., 1999), but when comparing UFM with RM and SM it was not observed, probably because UF disguises this effect. The digestion of milk proteins produces casein hydrolysis and the release of part of the bound minerals; digestion is also responsible for the formation of casein phosphopeptides associated with the enhanced solubility of minerals, such as $\mathrm{Ca}$, and a consequent increase in their bioavailability (Kitts, 2005; Boutrou et al., 2010). Future research is warranted on this issue.

The modified mineral distribution obtained with UF, alongside the higher casein concentration, may explain the better postfermentation curd formation observed after this process. According to (Polychroniadou and Vafopoulou, 1986), the equilibrium of salts between the aqueous and dispersed phase of milk affects its rennet coagulability and the physical properties of the curd. This improved curd may enhance the mineral bioavail-

Table 4. Total mineral (Ca, $\mathrm{P}, \mathrm{Mg}$, and $\mathrm{Zn}$ ) levels and Ca-to-P ratio in analyzed goat milk samples ${ }^{1}$ and levels associated with their $\mathrm{NCN}^{2}$ and NPN fractions (mean $\pm \mathrm{SD}$ )

\begin{tabular}{llccc}
\hline Mineral & Fraction & RM & SM & UFM \\
\hline Ca & Total & $135.2 \pm 10.0^{\mathrm{a} *}$ & $147.9 \pm 10.1^{\mathrm{b} *}$ & $165.6 \pm 15.1^{\mathrm{c} *}$ \\
& NCN & $109.5 \pm 6.4^{\mathrm{a} * * *}$ & $110.0 \pm 10.1^{\mathrm{a} * * *}$ & $152.0 \pm 7.4^{\mathrm{b} * * *}$ \\
$\mathrm{Ca}: \mathrm{P}$ & NPN & $94.2 \pm 13.1^{\mathrm{a} * * *}$ & $97.8 \pm 10.9^{\mathrm{a} * * *}$ & $138.8 \pm 11.7^{\mathrm{b} * * *}$ \\
$\mathrm{P}$ & Total & 1.36 & 1.39 & 1.20 \\
& Total & $101.2 \pm 15.5^{\mathrm{a} * * *}$ & $106.6 \pm 14.3^{\mathrm{a} * * *}$ & $139.7 \pm 10.4^{\mathrm{b} * * *}$ \\
& NCN & $82.1 \pm 7.7^{\mathrm{a} * *}$ & $84.2 \pm 13.3^{\mathrm{a} * *}$ & $113.6 \pm 16.7^{\mathrm{b} * *}$ \\
$\mathrm{Mg}$ & NPN & $49.4 \pm 5.7^{\mathrm{a} * * *}$ & $53.2 \pm 4.0^{\mathrm{a} * * *}$ & $70.2 \pm 7.1^{\mathrm{b} * * *}$ \\
& Total & $14.97 \pm 2.74^{\mathrm{a} *}$ & $15.74 \pm 2.26^{* *}$ & $16.67 \pm 1.32^{\mathrm{b} *}$ \\
$\mathrm{Zn}$ & NCN & $9.39 \pm 10.09^{\mathrm{a} * * *}$ & $9.45 \pm 1.32^{\mathrm{a} * * *}$ & $12.33 \pm 1.68^{\mathrm{b} * * *}$ \\
& NPN & $8.23 \pm 0.65^{\mathrm{a} * * *}$ & $8.73 \pm 0.758^{\mathrm{a} * * *}$ & $11.06 \pm 1.69^{\mathrm{b} * * *}$ \\
& Total & $408.4 \pm 32.8^{\mathrm{a} * * *}$ & $402.0 \pm 31.1^{\mathrm{a} * * *}$ & $616.4 \pm 79.2^{\mathrm{b} * * *}$ \\
& NCN & $337.5 \pm 93.1^{\mathrm{a} * * *}$ & $396.7 \pm 99.3^{\mathrm{a} * * *}$ & $548.2 \pm 111.5^{\mathrm{b} * * *}$ \\
\hline
\end{tabular}

\footnotetext{
${ }^{\mathrm{a}-\mathrm{c}}$ Different superscript letters indicate statistically significant differences among milks within a row.

${ }^{1} \mathrm{RM}=$ raw goat milk; SM = skimmed goat milk; UFM = skimmed goat milk concentrated by UF .

${ }^{2} \mathrm{NCN}=$ noncasein nitrogen fraction.

${ }^{*} P<0.05 ;{ }^{* *} P<0.01$; *** $P<0.001$.
} 
Table 5. Percentage of minerals (Ca, $\mathrm{P}, \mathrm{Mg}$, and $\mathrm{Zn}$ ) in goat milk samples ${ }^{1}$ associated with their casein and whey protein fractions $(\mathrm{n}=12)$

\begin{tabular}{|c|c|c|c|c|}
\hline Mineral & Fraction & $\mathrm{RM}$ & $\mathrm{SM}$ & UFM \\
\hline \multirow[t]{4}{*}{$\overline{\mathrm{Ca}}$} & Soluble $^{2}(\%$ total $)$ & 70 & 66 & 84 \\
\hline & Protein $^{3}(\%$ total $)$ & 30 & 34 & 16 \\
\hline & $\operatorname{Casein}^{4}$ (\% proteins) & 63 & 76 & 51 \\
\hline & Whey proteins ${ }^{5}$ (\% proteins) & 37 & 24 & 49 \\
\hline \multirow[t]{4}{*}{$\mathrm{P}$} & Soluble (\% total) & 49 & 50 & 50 \\
\hline & Protein (\% total) & 51 & 50 & 50 \\
\hline & Casein (\% proteins) & 37 & 42 & 38 \\
\hline & Whey proteins (\% proteins) & 63 & 58 & 62 \\
\hline \multirow[t]{4}{*}{$\mathrm{Mg}$} & Soluble (\% total) & 55 & 56 & 66 \\
\hline & Protein ( $\%$ total $)$ & 45 & 44 & 34 \\
\hline & Casein (\% proteins) & 83 & 90 & 67 \\
\hline & Whey proteins (\% proteins) & 17 & 10 & 23 \\
\hline \multirow[t]{4}{*}{ Zn } & Soluble (\% total) & 71 & 84 & 67 \\
\hline & Protein $(\%$ total $)$ & 29 & 16 & 33 \\
\hline & Casein (\% proteins) & 59 & 8 & 34 \\
\hline & Whey proteins (\% proteins) & 41 & 92 & 66 \\
\hline
\end{tabular}

${ }^{1} \mathrm{RM}=$ raw goat milk; SM = skimmed goat milk; UFM = skimmed goat milk concentrated by ultrafiltration. ${ }^{2}$ Soluble $(\%$ total $)=$ percentage of minerals not bound to proteins and soluble in the whey.

${ }^{3}$ Protein $(\%$ total $)=$ percentage of minerals supposedly bound to proteins.

${ }^{4}$ Casein $(\%$ proteins $)=$ percentage of minerals supposedly bound to caseins in relation to minerals bound to proteins.

${ }^{5}$ Whey proteins $(\%$ proteins $)=$ percentage of minerals supposedly bound to whey proteins in relation to minerals bound to proteins.

ability of the final yogurt product, as previously reported (Domagała, 2012).

In conclusion, concentrations of ash, density, acidity, total and whey proteins, caseins, and minerals $(\mathrm{Ca}, \mathrm{P}$, $\mathrm{Mg}$, and $\mathrm{Zn}$ ) were enhanced in UFM in comparison with RM or SM, whereas fat and dry extract values were higher in UFM than in SM. The UF process modified the mineral distribution, increasing $\mathrm{Ca}$ and $\mathrm{Mg}$ solubility in the UFM. The improved mineral and casein concentration in UFM and its low fat content make this milk nutritionally superior and more appropriate for goat yogurt manufacturing in comparison to RM or SM.

\section{ACKNOWLEDGMENTS}

This study was supported by project P09-AGR-4915 from the Consejería de Innovación, Ciencia y Empresa (Junta de Andalucía) and by a predoctoral scholarship for M. Moreno-Montoro from the Spanish Ministry of Education (Ref. AP2009- 3138). The authors are grateful to the farmers from Granada for the milk, Richard Davies (freelance English translator, Granada, Spain) for assistance with the English version, and María del Mar Salmerón-Restoy (Universidad de Granada, Granada, Spain) for technical support.

\section{REFERENCES}

AOAC International. 2012. Official Methods of Analysis. 19th ed. AOAC International, Gaithersburg, MD.
Baró Rodríguez, L., F. Lara Villoslada, and E. Corral Román. 2010. Capítulo 1. Leche y derivados lácteos. Pages 1-26 in Tratado de Nutricion. Tomo II: Composicion y calidad nutritiva de los alimentos. Á. Gil and M.D. Ruiz-López, ed. Editorial Médica Panamericana, Madrid, Spain.

Bergillos-Meca, T., C. Cabrera-Vique, R. Artacho, M. Moreno-Montoro, M. Navarro-Alarcón, M. Olalla, R. Giménez, and M. D. RuizLópez. 2015. Influence of milk ultrafiltration on $\mathrm{Ca}, \mathrm{Mg}, \mathrm{Zn}$ and $\mathrm{P}$ levels in fermented goats' milk. Small Rumin. Res. 124:95-100. http://dx.doi.org/10.1016/j.smallrumres.2015.01.005.

Bergillos-Meca, T., M. Navarro-Alarcón, C. Cabrera-Vique, R. Artacho, M. Olalla, R. Giménez, M. Moreno-Montoro, A. Ruiz-Bravo, A. Lasserrot, and M. D. Ruiz-López. 2013. The probiotic bacterial strain Lactobacillus fermentum D3 increases in vitro the bioavailability of Ca, P, and Zn in fermented goat milk. Biol. Trace Elem. Res. 151:307-314. http://dx.doi.org/10.1007/s12011-012-9544-0.

Boutrou, R., E. Coirre, J. Jardin, and J. Léonil. 2010. Phosphorylation and coordination bond of mineral inhibit the hydrolysis of the $\beta$-casein $(1-25)$ peptide by intestinal brush-border membrane enzymes. J. Agric. Food Chem. 58:7955-7961. http://dx.doi. org/10.1021/jf100568r.

Casado Cimiano, P. 1991. Guía para el análisis químico de la leche y los derivados lácteos. Ediciones Ayala y Revista ILE, Madrid, Spain.

de la Fuente, M. Á., J. Fontecha, and M. Juárez. 1996. Partition of main and trace minerals in milk: Effect of ultracentrifugation, rennet coagulation, and dialysis on soluble phase separation. J. Agric. Food Chem. 44:1988-1992. http://dx.doi.org/10.1021/jf9506949.

de la Fuente, M. A., A. Olano, V. Casal, and M. Juárez. 1999. Effects of high pressure and heat treatment on the mineral balance of goats' milk. J. Dairy Res. 66:65-72.

de la Fuente, M. A., A. Olano, and M. Juârez. 1997. Distribution of calcium, magnesium, phosphorus, zinc, manganese, copper and iron between the soluble and colloidal phases of ewe's and goat's milk. Lait 77:515-520.

Domagała, J. 2009. Instrumental texture, syneresis and microstructure of yoghurts prepared from goat, cow and sheep milk. Int. J. Food Prop. 12:605-615. http://dx.doi.org/10.1080/10942910801992934.

Domagała, J. 2012. Instrumental texture, syneresis, and microstructure of yoghurts prepared from ultrafiltrated goat milk: Effect of 
degree of concentration. Int. J. Food Prop. 15:558-568. http:// dx.doi.org/10.1080/10942912.2010.492545.

Domagala, J., and B. E. Kupiec. 2003. Changes in texture of yoghurt from ultrafiltrated goats' milk as influenced by different membrane types. Electron. J. Polish Agric. Univ. 6:5

Fransson, G.-B., and B. Lönnerdal. 1983. Distribution of trace elements and minerals in human and cow's milk. Pediatr. Res. 17:912-915. http://dx.doi.org/10.1203/00006450-198311000-00015.

Gonzalez-Crespo, J., M. Lozano, M. Mas, and A. Serrano. 1995. Producción y composición química de la leche de cabra verata. Alimentaria 263:53-58.

Güler, Z. 2007. Levels of 24 minerals in local goat milk, its strained yoghurt and salted yoghurt (tuzlu yoğurt). Small Rumin. Res. 71:130-137. http://dx.doi.org/10.1016/j.smallrumres.2006.05.011.

Güler-Akın, M. B., and M. S. Akın. 2007. Effects of cysteine and different incubation temperatures on the microflora, chemical composition and sensory characteristics of bio-yogurt made from goat's milk. Food Chem. 100:788-793. http://dx.doi.org/10.1016/j.foodchem.2005.10.038

Güler-Akin, M. B., M. Serdar Akin, and A. Korkmaz. 2009. Influence of different exopolysaccharide-producing strains on the physicochemical, sensory and syneresis characteristics of reduced-fat stirred yoghurt. Int. J. Dairy Technol. 62:422-430. http://dx.doi. org/10.1111/j.1471-0307.2009.00499.x.

ISO. 2008. Milk-Determination in fat content. ISO 2446:2008 (IDF 226:2008). International Organization for Standardization, Geneva, Switzerland.

Karam, M. C., C. Gaiani, C. Hosri, J. Burgain, and J. Scher. 2013. Effect of dairy powders fortification on yogurt textural and sensorial properties: A review. J. Dairy Res. 80:400-409. http://dx.doi. org/10.1017/S0022029913000514.

Kitts, D. D. 2005. Antioxidant properties of caseinphosphopeptides. Trends Food Sci. Technol. 16:549-554. http://dx.doi org/10.1016/j.tifs.2005.08.009.

Lara-Villoslada, F., M. Olivares, J. Jiménez, J. Boza, and J. Xaus. 2004. Goat milk is less immunogenic than cow milk in a murine model of atopy. J. Pediatr. Gastroenterol. Nutr. 39:354-360. http://dx.doi.org/10.1097/00005176-200410000-00010.

Marafon, A. P., A. Sumi, M. R. Alcântara, A. Y. Tamime, and M. Nogueira de Oliveira. 2011. Optimization of the rheological properties of probiotic yoghurts supplemented with milk proteins. LWT Food Sci. Technol. (Campinas.) 44:511-519. http://dx.doi. org $/ 10.1016 /$ j.lwt.2010.09.005

Martín-Diana, A. B., C. Janer, C. Peláez, and T. Requena. 2003. Development of a fermented goat's milk containing probiotic bacteria. Int. Dairy J. 13:827-833. http://dx.doi.org/10.1016/S09586946(03)00117-1.

Moreno-Torres, F., M. Navarro, M. D. Ruiz-López, R. Artacho, and M. López. 2000. Comparison of wet and dry mineralisation procedures for determining calcium and phosphorous in cow's milk. Aust. J. Dairy Technol. 55:23-27.

Navarro-Alarcón, M., C. Cabrera-Vique, M. D. Ruiz-López, M. Olalla, R. Artacho, R. Giménez, V. Quintana, and T. Bergillos. 2011. Levels of $\mathrm{Se}, \mathrm{Zn}, \mathrm{Mg}$ and $\mathrm{Ca}$ in commercial goat and cow milk fermented products: Relationship with their chemical composition and probiotic starter culture. Food Chem. 129:1126-1131. http:// dx.doi.org/10.1016/j.foodchem.2011.05.090.

Olalla, M., M. D. Ruiz-López, M. Navarro, R. Artacho, C. Cabrera, R. Giménez, C. Rodriguez, and R. Mingorance. 2009. Nitrogen fractions of Andalusian goat milk compared to similar types of commercial milk. Food Chem. 113:835-838. http://dx.doi. org/10.1016/j.foodchem.2008.10.022.

Park, Y. W., M. Juárez, M. Ramos, and G. F. W. Haenlein. 2007. Physico-chemical characteristics of goat and sheep milk. Small Rumin. Res. 68:88-113. http://dx.doi.org/10.1016/j smallrumres.2006.09.013.

Polychroniadou, A., and A. Vafopoulou. 1986. Salt distribution between the colloidal and soluble phases of ewes' milk. J. Dairy Res. 53:353-358. http://dx.doi.org/10.1017/S0022029900024973.

Quiles Sotillo, A., and M. L. Hevia Méndez. 1994. La Leche de cabra. Editorial Universidad de Murcia, Murcia, Spain.

Ramos-Morales, E., G. de la Torre-Adarve, F. D. Carmona-López, F. Gil-Extremera, M. R. Sanz-Sampelayo, and J. Boza. 2005. Nutritional value of goat and cow milk protein. Pages $167-170$ in Sustainable grazing, nutritional utilization and quality of sheep and goat products. E. Molina Alcaide, H. Ben Salem, K. Biala and P. Morand-Fehr, ed. CIHEAM (Options Mediterranéennes, Series A), Zaragosa, Spain.

Raynal-Ljutovac, K., G. Lagriffoul, P. Paccard, I. Guillet, and Y Chilliard. 2008. Composition of goat and sheep milk products: An update. Small Rumin. Res. 79:57-72. http://dx.doi.org/10.1016/j smallrumres.2008.07.009.

Rinaldoni, A. N., M. Campderros, C. J. Menendez, and A. Pérez Padilla. 2009. Fractionation of skim-milk by an integrated membrane process for yoghurt elaboration and lactose recuperation. Int. J. Food Eng. 5:1-17.

Roig, M. J., A. Alegría, R. Barberá, R. Farré, and M. Lagarda. 1999. Calcium bioavailability in human milk, cow milk and infant formulas - Comparison between dialysis and solubility methods. Food Chem. 65:353-357. http://dx.doi.org/10.1016/S03088146(98)00232-5.

Sanz Ceballos, L., E. Ramos Morales, G. de la Torre Adarve, J. Díaz Castro, L. Pérez Martínez, and M. R. Sanz Sampelayo. 2009. Composition of goat and cow milk produced under similar conditions and analyzed by identical methodology. J. Food Compos. Anal 22:322-329. http://dx.doi.org/10.1016/j.jfca.2008.10.020.

Slačanac, V., R. Božanić, J. Hardi, J. Rezessyné Szabó, M. Lučan, and V. Krstanović. 2010. Nutritional and therapeutic value of fermented caprine milk. Int. J. Dairy Technol. 63:171-189. http:// dx.doi.org/10.1111/j.1471-0307.2010.00575.x.

Stelios, K., and A. Emmanuel. 2004. Characteristics of set type yogurt made from caprine or ovine milk and mixtures of the two. Int. J. Food Sci. Technol. 39:319-324. http://dx.doi.org/10.1111/j.13652621.2004.00788.x.

Tamime, A. Y., M. Wszolek, R. Božanić, and B. Özer. 2011. Popular ovine and caprine fermented milks. Small Rumin. Res. 101:2-16. http://dx.doi.org/10.1016/j.smallrumres.2011.09.021.

Tamime, A. Y., and R. K. Robinson. 2007. Tamime \& Robinson's Yoghurt: Science and Technology. CRC Press, Boca Raton, FL. 